\title{
Особливості проведення змагань в кільцевих автоперегонах (на прикладі «Формула-1» та «NASCAR»)
}

\author{
Олег Білик, Христина Хіменес
}

Львівський державний університет фізичної культури імені Івана Боберського, Львів, Україна

Анотація. Популярність професійних автоперегонів постійно зростає, відповідно організатори подібних змагань прагнуть до удосконалення їх проведення. Важливим фактом є утримання глядацької уваги, а отже існує необхідність у забезпеченні непередбачуваності переможця таких змагань. Найуспішнішими моделями змагальних систем у класі кільцевих видів є Гран-прі змагань Формули-1 та суперсерія NASCAR. Мета. Виявити спільні та відмітні риси проведення змагань в автоперегонах «Формула-1» та «NASCAR». Методи. Аналіз та узагальнення даних наукової та методичної літератури, документальних матеріалів. Результати. У сучасному суспільстві професійні автоперегони характеризуються динамічністю, непередбачуваністю змагальної діяльності та водночас екстремальними, небезпечними, але економічно виправданими підходами до змагань. Виявлено загальні критерії для пошуку спільних та відмітних рис у системі проведення змагань «Формула-1» та «NASCAR», які включають кількість команд, пілотів, змістову частину гонок, систему нарахування очок, наявність «плей-оффф», тривалість гонки, кількість та тривалість «піт-стопів» за гонку, властивості змагального треку чи траси, гендерну ознаку, географрію проведення змагань, участь «Grid girls». Відповідно було з'ясовано характерні особливості систем змагань у професійних автоперегонах за кожним з визначених критеріїв. Обґрунтовано компоненти економічної ефективності систем змагань, які включають середні витрати на сезон для команд, розподіл прибутків, відвідуваність, максимальну заробітню платню, вартість автомобіля та квитків.

Зіставлення інформації про проведення змагань з професійних кільцевих автоперегонів дозволило виявити, що організатори «NASCAR» дотримуються більш традиційних підходів до формування системи змагань, а організатори «Формули-1» постійно актуалізують складові змагальної діяльності відповідно до високих технологічних вимог.

Ключові слова: система змагань, професійні автоперегони, «Формула-1», «NASCAR».

\section{Oleh Bilyk, Khrystyna Himenes}

\section{FEATURES OF COMPETITIONS IN RING RACES («FORMULA 1»AND «NASCAR»)}

Abstract. The popularity of professional car races is constantly growing. Therefore, their organizers seek to improve their conduct. An important fact is to keep the audience's attention, and therefore there is a need to ensure the unpredictability of the winner of such competitions. The most successful models of competitive systems in the ring races are the Grand Prix of Formula 1 competitions and the NASCAR superseries. Objective. Identification of common and distinctive features of Formula 1 and NASCAR races. Methods. Analysis and generalization of data of scientific and methodical literature, documentary materials. Results. In modern society, professional car racing is characterized by dynamism, unpredictability of competitive activities and at the same time extreme, dangerous, but economically justified approaches to competition. The general criteria for finding common and distinctive features in the system of holding «Formula 1 » and «NASCAR» competitions have been identified, which include the number of teams, pilots, the content of the races, the scoring system, the availability of «playoffs», the duration of the race, the number and duration of «pit stops» per race, properties of the competition track, gender, geography of the competition holding, participation of «Grid girls». The characteristics of the competition systems in professional car racing were determined according to each of the defined criteria. The components of economic efficiency of competition systems are substantiated, which include average costs per season for teams, distribution of profits, attendance, maximum salary, cost of car and tickets.

Bilyk 0, Himenes Kh. Features of competitions in ring races («Formula 1» and «NASCAR»). Theory and Methods of Physical education and sports. 2020; 4: 7-12 DOI: 10.32652/tmfvs.2020.4.7-12
Білик 0, Хіменес Х. Особливості проведення змагань в кільцевих автоперегонах (на прикладі «Формула-1» та «NASCAR»). Теорія і методика фрізичного виховання і спорту. 2020; 4: 7-12

DOI: 10.32652/tmfvs.2020.4.7-12
Вступ. Сучасні моделі систем змагань у профресійному спорті спрямовані на реалізацію підходів до забезпечення непередбачуваності переможця протягом усього сезону. Це стимулює зацікавленість до змагань глядачів, засобів масової інфрормації, спонсорів, рекламодавців, а отже сприяє зростанню прибутків. Такий підхід бере початок із США кінця XIX-початку XX ст. Це період активізації науково-технічного прогресу. Саме тоді і зароджуються спортивні змагання під назвою автоперегони [2, 4, $10,20]$.

Аналіз наукових джерел дає змогу сформулювати актуальне термінологічне визначення цього виду професійних змагань. Так, автоперегони - це категорія технічних видів спорту, в яких люди змагаються в швидкості проходження змагальної траси на різних типах автомобільної техніки (прототипи, легкові автомобілі тощо) [1, 3 , 11, 18]. Згідно з класифрікацією ряду авторів $[3,6,8,16]$, цей вид спорту належить до другої групи, де рухова діяльність спортсмена спрямована на управління засобами пересування (автомобілями, літаками, мотоциклами, яхтами тощо).

У сучасному суспільстві професійні автоперегони характеризуються динамічністю, непередбачуваністю змагальної діяльності та водночас екстремальними, небезпечними, проте економічно виправданими підходами до проведення змагань $[7,13,14]$.

На думку значної кількості спеціалістів $[2,4,9,15]$, найбільш вдалими моделями систем змагань у класі шосейно-кільцевих видів $є$ автоперегони Гран-прі «Формула-1» та супер серії «NASCAR». Тому теоретичне порівняння спільних та відмітних рис, які будуть відображати особливості проведення змагань у цих видах професійних автоперегонів, $€$ актуальним завданням. 
Comparison of information on holding competitions in professional ring racing revealed that the organizers of «NASCAR» follow a more traditional approaches to the formation of the competition system, whereas those of «Formula 1» are constantly updating the components of competitive activities in accordance with high technological requirements.

Keywords: competition system, professional car races, «Formula-1», «NASCAR».

Мета дослідження-виявити спільні та відмітні риси проведення змагань в автоперегонах «Формула-1» та «NASCAR».

Методи дослідження: аналіз та узагальнення даних наукової та методичної літератури, документальних матеріалів, відеоспостереження змагальної діяльності.

Результати дослідження та їх обговорення. Першочерговим завданням реалізації поставленої мети даного наукового дослідження було з'ясування відповідальності за організацію та проведення змагань в автоперегонах. У «Формулі-1» керівною структурою $є$ Міжнародна автомобільна фредерація (FIA - фрp. Fédération Internationale de l'Automobile). Над автоперегонами «NASCAR» керівництво здійснює National Association Stock Car Racing (NASCAR), яка знаходиться у володінні сім'ї Франс зі Сполучених Штатів Америки [5, 8, 12, 17].

Незважаючи на різні організаційні структури, які здійснюють керівництво професійними автоперегонами «Формула-1» та «NASCAR», нами було встановлено критерії, які визначають особливості проведення змагань у цих шосейно-кільцевих видах.

Історично склалось так, що у різні періоди свого розвитку професійні автоперегони «Формули-1» та «NASCAR» мали різні за кількістю склади учасників $[3,6,13,19]$. На сьогодні «Формула-1» включає 10 команд та 30 пілотів, двоє з яких - основні і виступають відповідно під першим або другим номером кожної з команд. Також кожна команда відповідно до регламенту змагань має ще по одному резервному пілоту.

У змаганнях найпрестижнішої серії «NASCAR», повна назва якої станом на сезон 2019 р. іменувалася як «Monster Energy NASCAR Cup Series», участь беруть 20 команд, кількість пілотів в одній команді може бути від 1 до 10 залежно від можливостей ко- манд. Загалом за сезон 2019 р. участь у цих змаганнях брали 32 гонщики Ще однією рисою цих автоперегонів $\epsilon$ те, що кожна команда, а в деяких випадках екіпаж команди, мають по одному так званому «Crew chief», тобто керівнику, який стежить за допомогою відеокамер в режимі «он-лайн» за ходом автоперегонів і дає поради пілоту зі спеціальної кабіни в межах автодрому.

Важливим моментом, який впливає на організацію і проведення змагань у супер-серії «NASCAR», $€$ те, що команди забезпечують лише три виробники автомобілів: «Chevrolet», «Toyota», «Ford». Щодо «Формули-1», то такий принцип тут не враховують, оскільки боліди не використовуються у серійному виробництві, а потребують значної модифрікації. Це й визначає суттєву різницю у вартості гоночних автомобілів для цих змагань: y «NASCAR» вона становить близько 1,5 млн дол., а у «Формулі-1» - близько 7 млн дол. [12, 14, 16, 18].

Цікавим аспектом проведення змагань у профресійних автоперегонах, який забезпечує непередбачуваність результату змагань від початку до завершення сезону, є система нарахування очок як за окремий етап, так і загалом за сезон.

у «Формулі-1» система нарахування очок розраховується за таким принципом: 1-ше місце - 25 очок, 2-ге - 18, 3-тє - 15, 4-те - 12, 5-те 10, 6-те - 8, 7-ме - 6, 8-ме - 4, 9-те - 2 , 10-те місце - 1. Цей принцип нарахування зберігається і для «Кубку конструкторів Формула-1», де участь беруть всі 10 команд, на противагу «NASCAR», де в аналогічному випадку боротьбу ведуть тільки безпосередньо виробники автомобілів. Зважаючи на те що у гонці від команди беруть участь два екіпажі, їхні очки у підсумку додаються. Наприкінці сезону переможці визначаються за загальною сумою набраних очок у кожній гонці, проте відповідальні організаційні структури залишають за собою право знімати здобуті залікові бали у разі накладання на команду штрафрних санкцій.

у просресійних автоперегонах «NASCAR» система нарахування балів має свої відмінності. До 2011 р. вона нараховувала залікові бали за гонку всім пілотам команд, які досягали фрінішу. За перше місце у гонці команді (пілоту) нараховувалося 185 залікових балів, за 2-ге місце - 170 , за 3-тє - 165, за 4-те - 160, за 5-те 155, за 6-те - 150, за 7-ме - 146, за 8-ме - 142, за 9-те - 138, за 10-те 134 бали. Наприкінці сезону для визначення переможців бали додавали, проте існувала можливість їх зняття за порушення під час гонки. 32011 р. система нарахування балів змінилась, оскільки керівництво автоперегонів вирішило її актуалізувати [11]. Так, 3 цього часу переможець гонки отримує 46 балів, за 2-ге місце - 42, 3-тє місце - 41, далі в порядку спадання бали нараховують до 43-го місця, за яке надається лише один бал. Додатковий бал нараховується за лідерство хоча б в одному колі гонки і за лідерство в більшості кіл.

Особливою рисою автоперегонів «NASCAR» 32004 р. є те, що окрім регулярного чемпіонату, який включає 36 етапів, розпочинаючи з 26-го, вводиться система «чейз», більш відома як «Гонка за кубком», що за специфрікою відповідає системі «плей-оффф». Суть полягає в тому, що 16 пілотів, які протягом сезону здобули найбільшу кількість перемог, отримують по 2000 балів, а їхні попередні здобутки анулюються, і до кінця сезону вони в загальній групі учасників розігрують між собою перемогу у змаганнях «NASCAR». При тому «чейз» триває чотири раунди, де до фрінального доходять лише чотири кращих гонщики в останньому, 36-му, етапі. Варто зазначити, що всі інші пілоти також беруть участь, але вже з метою забезпечення видовищності, тактичної допомоги партнерам по команді, або ж перешкоди учасникам «чейз». Проте вони все ж претендують на частину призового фонду, який розігруєть- 


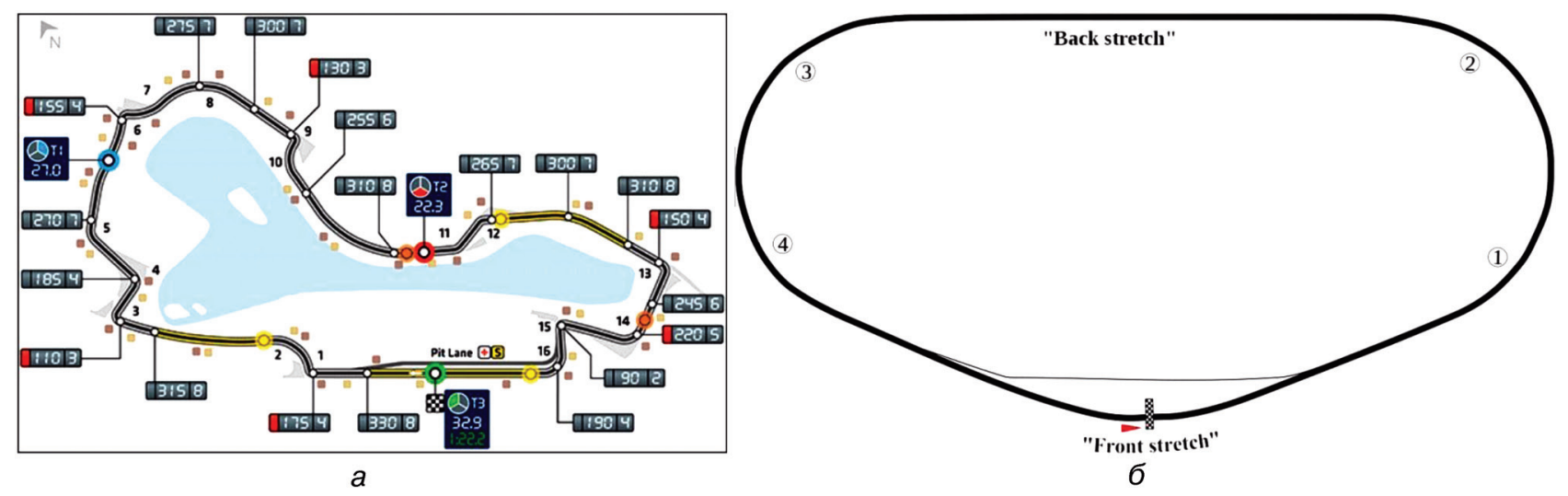

Рисунок 1 - Змагальні автодроми:

a- Гран-прі «Формули-1» в Австралії; б- «Monster Energy NASCAR Cup Series» в Дайтоні

ся у кожному етапі і становить від 2 до 7 млн дол. [9, 12].

Окрім індивідуального результату ведеться окремий залік серед трьох команд-виробників автомобілів та команд-учасників за принципом додавання набраних балів відповідними пілотами кожної $з$ команд.

Просресійні змагання найвищої сеpiï «NASCAR» та етапи Гран-прі «Формули-1» мають характерну спільну рису у змістовій частині гонки. Обидва змагання включають практики, кваліфрікаційні заїзди та власне перегони. При цьому збігаються і стартові дні - п'ятниця, субота та неділя.

Відмінностей у їх проведенні теж достатньо. Тривалість гонки без зупинок у «Формулі-1» відповідно до регламенту змагань не повинна перевищувати 2 год, 3 мінімальною протяжністю всіх кіл до 305 км (виняток - Гран-прі Монако - 260 км), а у «NASCAR» можуть тривати близько 3-3,5 год. Особливість автоперегонів супер-серії «NASCAR» полягає також у специфічній властивості змагального треку, який у більшості перегонів має овальну форму (34 етапи із 36) зі звичайним ассральтовим та бетонним покриттям і не має великої кількості поворотів на дистанції, оскільки гонки організовані по коловій дистанції. у «Формулі-1» використовуються автодроми у вигляді замкнутого кільця із значною кількістю поворотів різної складності, де основна траса асфральтована, а відрізки «зон безпеки» складаються з гравію (рис. 1).

Кількість «піт-стопів» під час однієї гонки в обох видах професійних автоперегонів $є$ ідентичною і складається 3 двох регламентованих зупинок, проте їх тривалість відрізняється. Так, у «Формулі-1» це 4-5 с, оскільки специфіка перегонів тут спрямована на швидкість у всіх її аспектах, що зумовлює велику кількість доведених до автоматизму дій з боку технічного персоналу, який складається 312 механіків безпосередньо на «піт-лейні». При цьому вони забезпечені в своїй роботі сучасним комп'ютерним обладнанням.

B автоперегонах «NASCAR» «пітстоп» триває 13-15 с. Це пов'язано 3 тим, що кількість механіків не перевищує семи і дозаправка здійснюється вручну звичайними баками 3 пальним, що є невід'ємною традицією ще з моменту заснування автоперегонів у $1948 \mathrm{p}$.

Географрія проведення сучасних автоперегонів «Формули-1» досить широка, оскільки станом на 2020 р. вони проходять в Австралії, Бахрейні, Китаї, Азербайджані, Іспанії, Франції, Канаді, Австрії, Великій Британії, Німеччині, Угорщині, Бельгії, Італії, Сингапурі, Росії, Японії, США, Мексиці, Бразилії, ОАЕ. Основні автоперегони «NASCAR» традиційно проводяться лише на території США, хоча фарм-серіï «NASCAR Camping World Truck Series Standings» та «NASCAR Xfinity Series Standings» проходять у Канаді та Мексиці.

Участь жінок у професійних автоперегонах, зважаючи на високий рівень небезпеки, обмежена. Так, у «Формулі-1» протягом усієї історії іс- нування жінки не брали участі у змаганнях, а у «NASCAR» був лише один прецедент з Данікою Патрік, яка досить успішно проявляла свою майстерність, про що свідчать її прибутки за сезон 2012 р., які становили 12,9 млн дол.

Для надання більш видовищного ефекту проведенню змагань організаторами різних автоперегонів використовуються так звані «Grid girls» (дівчата-моделі) на церемонії нагородження, що, на думку багатьох фрахівців, стимулює глядачів до відвідування серій перегонів. Проте, якщо у «NASCAR» такий метод $є$ актуальним, то у «Формулі-1», розпочинаючи з сезону 2018 р., такий підхід відмінено. Організатори стверджують, що керуються в цьому випадку лише етичними та моральними нормами [5].

Характерні особливості систем змагань автоперегонів «Формула-1» та «NASCAR» представлено у таблиці 1.

Окрім внутрішніх особливостей проведення автоперегонів «Формула-1» та «NASCAR» доцільно з'ясувати окремі економічні закономірності їх формування, оскільки вони також мають вплив на удосконалення систем цих змагань. Важливим питанням у цьому $€$ виявлення фрінансових витрат за сезон для команд. У «Формулі-1», за даними інсрормаційних джерел [8-10], вони в середньому становлять 200 млн дол., а у «NASCAR» - 20 млн дол. Обґрунтовується це тим, що у першому випадку акцент зроблено на постійний техно- 
Т а б л и ц я 1. Особливості проведення змагань у професійних видах шосейно-кільцевих автоперегонів

\begin{tabular}{|c|c|c|}
\hline Критерії & «ASCAR» & «Формула-1» \\
\hline Кількість команд & 20 & 10 \\
\hline Кількість пілотів & 59 & 30 \\
\hline Система нарахування очок & Залікові очки отримують 43 пілоти & Перших 10 пілотів \\
\hline «Плей-офф» & Система «чейз» & Немає \\
\hline Змістова частина гонок & Кваліфікація, практика, власне перегони & Кваліфікація, практика, власне перегони \\
\hline Дні змагань & П'ятниця, субота, неділя & П'ятниця, субота, неділя \\
\hline Тривалість гонки & 3-3,5 год & 2 год \\
\hline Специфіка змагальної траси & Овальна форма & $\begin{array}{l}\text { Замкнуте кільце із значною кількістю } \\
\text { поворотів }\end{array}$ \\
\hline Кількість «піт-стопів» за гонку & 2 & 2 \\
\hline Тривалість «піт-стопів» & $13-15 c$ & $4-5 c$ \\
\hline Гендерна ознака & Допускається участь жінок & Жінки не допускаються \\
\hline Територія проведення автоперегонів (2018р.) & США & 21 країна \\
\hline $\begin{array}{l}\text { Участь «Grid girls», або дівчат-моделей } \\
\text { на церемонії нагородження }\end{array}$ & Наявна & Відмова з сезону 2018 р. \\
\hline
\end{tabular}

Т а б л и ц я 2. Економічні показники проведення змагань у професійних автоперегонах «NASCAR» та «Формула-1»

\begin{tabular}{|c|c|c|}
\hline Критерії & «ASCAR» & «Формула-1» \\
\hline Середні витрати на сезон для команди & 20 млн дол. США & 200 млн дол. США \\
\hline Розподіл прибутків & $\begin{array}{l}50 \text { \% - власники, комерційних прав, } \\
47,5 \text { \% - десять кращих команд; } \\
\text { 2,5 \% - бонус Ferrari }\end{array}$ & $\begin{array}{l}\text { Власники автодромів - } 65 \text { \%; } \\
\text { команди - } 25 \% \text {; } \\
\text { організатори - } 10 \%\end{array}$ \\
\hline Відвідуваність глядачів (рекордна) & 182000 тис. осіб & 298000 тис. осіб \\
\hline $\begin{array}{l}\text { Максимальна заробітна плата (станом на сезон } \\
2012 \text { р.) }\end{array}$ & 28 млн дол. & 37 млн. дол. \\
\hline Вартість автомобіля & Близько 1,5 млн дол. США & Близько 7 млн дол. США \\
\hline Вартість квитка на гонку & від 55 до 100 дол. США & від 100 до 2000 дол. США \\
\hline
\end{tabular}

логічний розвиток, який потребує значних фрінансових затрат, а в другому витрати в основному пов'язані із ремонтом та конструюванням нових автомобілів, які, відповідно до специфіки гонки, часто пошкоджуються. Водночас технічна складова не є надто затратною порівняно з витратами на боліди у «Формулі-1».

Важливим у регулюванні економічної взаємодії команд у професійних автоперегонах є розподіл прибутків за сезон. Відомо, що у «Формулі-1» 50 \% прибутку отримують власники комерційних прав; 47,5 \% - десять кращих команд у «Кубку Кон- структорів»; 2,5 \% - бонус автоконцерну «Ferrari». $\mathrm{y}$ «NASCAR» прибутки розподіляються за таким принципом: власники автодромів отримують $65 \%$, команди - $25 \%$, організатори - $10 \%$ [2, 7, 20].

Відвідуваність гонок у «Формулі-1» та «NASCAR» досить висока, і в обох випадках перевищує 100 тис. на кожен етап. Наприклад, найвищим показником відвідуваності у «Формулі-1» відзначився етап «Гран-прі Австралії» 2011 р. Тоді кількість глядачів становила 298 000. Максимальний показник за одну гонку у «NASCAR» був зафріксований на треку «Daytona 500» (2012 р.) - 182000 глядачів [1, 13].

Висока конкуренція у професійних автоперегонах сприяє і заробітній платні учасників змагань, наприклад, у «Формулі-1» Фернандо Алонсо у сезоні 2012 р. отримав 37 млн дол., а в «NASCAR» Дейл Ернхардт зміг заробити 28 млн дол. за один сезон.

Вартість квитків на одну гонку у «NASCAR» становить від 55 до 100, а у «Формулі-1» від 100 до 2000 дол. США.

Окремі економічні показники проведення змагань досліджуваних різ- 
новидів автоперегонів представлено у таблиці 2.

Отже, проведений аналіз дозволив виявити, що змагання в автоперегонах «Формула-1» і «NASCAR» мають свої характерні особливості. При цьому нами виявлено деякі спільні, проте переважно відмітні риси їх організації. Це пов'язано зі специфрікою ведення спортивного бізнесу на американському і європейському континентах, а також окремими традиціями, які сфрормувалися в процесі еволюції систем змагань цих автоперегонів.

Висновки. Структурами, котрі відповідальні за організацію і проведення змагань у професійних автоперегонах «NASCAR» та «Формула-1» створюється така концепція систем змагань, яка забезпечувала б непередбачуваність переможця від початку до завершення сезону. Проте в «NASCAR», судячи 3 представлених фактів, вона втілюється більш ефективно, оскільки існує так звана система «чейз», яка відтворює основні принципи «плей-офрф» і, відповідно, унеможливлює визначення переможця завчасно до завершення чемпіонату.

у «Формулі-1» підхід визначення переможця спрямований винятково на результати регулярного чемпіонату, що дає можливість виграти змагальний сезон за кілька етапів до завершення, набравши недосяжну для конкурентів кількість балів.

Варто відмітити високу фрінансову витратність та водночас значний прибуток від наданих послуг обох професійних змагань, але в автоперегонах «Формула-1» вони значніші порівняно 3 «NASCAR».

Автоперегони «NASCAR» дотримуються традиційної концепції заохочення глядачів у різних аспектах змагальної діяльності, які зберігаються ще 3 минулого століття, що не є характерним для «Формули-1», яка постійно актуалізує аналогічні аспекти. Це пов'язано із введенням у роботу новітніх комп'ютерних технологій та мінімізацією небезпеки для вболівальників і пілотів команд.

Перспективи подальших досліджень передбачають вивчення еволюції систем змагань у інших видах просресійних автоперегонів («Чемпіонат світу 3 класичного ралі», «Чемпіонат світу з автоперегонів на витривалість», ралі-рейд «Dakar», «Verizon IndyCar Series», «Чемпіонат світу 3 ралі-кросу», «Чемпіонат світу 3 турингових автоперегонів») з урахуванням різних критеріїв забезпечення їх есрективності, що дасть змогу обґрунтувати, зіставити та виявити особливості систем змагань у різних видах профресійних автоперегонів.

Конфлікт інтересів. Автори заявляють, що відсутній будь-який конфлікт інтересів.

\section{ЛIТЕРАТУРА}

1. Білик 0. Місце автоперегонів у системі професійних видів спорту. В.: Матеріали II Всеукр. студ. наук. конф. «Фізична культура, спорт та здоров'я». Харків; 2012. С. 14-16.

2. Бріскін ЮА, Линець ММ. Соціально економічні аспекти гонок «Формула-1». В. Актуальні проблеми фріз. виховання студентів та учнів, молоді Львівщини. Зб. наук. праць. Львів 2003. С. 25-8.

3. Васильчук И. Особености организации и проведения соревнований в автоспорте. В.: Спорт та сучасне суспільство: матеріали V Відкритої студент. наук. конф. Київ; 2012. 4: 85-9.

4. Линець ММ. Економічна есективність систем змагань в командних ігрових видах професіонального спорту. В.: Сучасні проблеми розвитку теорії та методики спортивних і рух ливих ігор. Тези III Всеукр. наук.-практ. конф Львів; 1999. С. 18-9.

5. Шахов А. Америка - страна чудес. Команда - плюс. 2002; 10: 58-65

6. Arron S, Hughes M. (2003) The Complete Book of Formula One. Motorbooks International. Hardcover; 2008. 567 p.

7. Cain L, Haddock D. (2005). Similar Economic Histories, Different Industrial Structures: Transatlantic Contrasts in the Evolution of Professional Sports Leagues. The Journal of Economic History. 2005; 65(4): 1116-47. doi:10.1017/ S0022050705000422.

8. Christian N. 1946-1983. Les Grand Prix de Formule 1 hors championnat du monde. Commentaires, resultats, statistiques. Editions du Palmier 2002. $150 \mathrm{pp}$

9. Depken C, Groothuis P, Rotthoff K. Family Connections in Motorsports: The Case of Formula One. Working Papers. Department of Economics. Appalachian State University. 2016. 34 p.

10. Euchner C. Home Team: Professiona Sports and the American Metropolis. Princeton NJ: Princeton University Press; 1998. 397 p. doi:10.2307/2585965

11. FIA Regulations [Internet]. [cited 2018 Jan. 3]. Available from: http://www.fia.com/sport/ regulations/

12. Gallian J. NASCAR. Mathematics and Sports; 2010. p. 187-8.

13. Hendrick Motorsports Tops List Of Nascar's Most Valuable Teams [Internet]. [cited 2018
Feb. 12]. Available from: http://www.forbes.com/ sites/kurtbadenhausen/2013/03/13/hendrickmotorsports-tops-list-of-nascars-most-valuableteams/

14. International Journal of Sport Finance [Internet]. [cited 2018 Jan. 16]. Available from: http:// ijsf.wordpress.com.

15. Jones B. (2005). The Guide to 2005 FIA Formula One World Championship: The World's Bestselling Grand Prix Guide. Carlton; 2005

16. Lucsko D. Real NASCAR: White Lightning, Red Clay, and Big Bill France. Chapel Hill, North Carolina: University of North Carolina Press; 2010 $348 p$.

17. Menard P. The Great Encyclopedia of Formula 1. 5th edition. Chronosport, Switzerland 2006. $49 \mathrm{p}$

18. Miltner H. Race Travel Guide 2007. Vienna, Austria; $2007.68 \mathrm{p}$

19. Standings NASCAR [Internet]. [cited 2018 Jan. 15]. Available from: http://www.nascar.com/ en_us/sprint-cup-series/standings.html

20. Vamplew W. (1988). Pay Up and Play the Game. Professional Sport in Britain. Cambridge: Cambridge University Press; 1988. 65 p doi:10.1017/CB09780511560866

\section{LITERATURE}

1. Bilyk 0. Place of car races in the system of professional sports events. In.: Materialy II Vseukr. stud. nauk. konf. «Fizychna kultura, sport ta zdorovia». Kharkiv; 2012. P. 14-16.

2. Briskin IA, Lynets MM. Socioeconomic aspects of «Formula- 1 » races. In.: Aktualni problemy fizvykhovannia studentiv ta uchniv, molodi Lvivshchyny. Zb. nauk. prats. Lviv; 2003. P. 25-8.

3. Vasilchuk I. Peculiarities of organizing and holding car competitions. In.: Sport ta suchasne suspilstvo: materialy V Vidkrytoi student. nauk konf. Kyiv; 2012. 4: 85-9

4. Lynets MM. Economic efficiency of competition system in team professional sports events. In.: Suchasni problem rozvytky teorii ta metodyky ihor. Tezy III Vseukr. nauk.-prakt. konf. Lviv; 1999 P. 18-9.

5. Shakhov A. America - the wonderland Team - plus. 2002; 10: 58-65.

6. Arron S, Hughes M. (2003) The Complete Book of Formula One. Motorbooks International Hardcover; 2008. 567 p.

7. Cain L, Haddock D. (2005). Similar Economic Histories, Different Industrial Structures: Transatlantic Contrasts in the Evolution of Professional Sports Leagues. The Journa of Economic History. 2005; 65(4): 1116-47. doi:10.1017/S0022050705000422.

8. Christian N. 1946-1983. Les Grand Prix de Formule 1 hors championnat du monde. Commentaires, resultats, statistiques. Editions du Palmier; 2002. $150 \mathrm{pp}$

9. Depken C, Groothuis P, Rotthoff K. Family Connections in Motorsports: The Case of Formula One. Working Papers. Department of Economics. Appalachian State University. 2016. 34 p.

10. Euchner C. Home Team: Professional Sports and the American Metropolis. Princeton, NJ: Princeton University Press; 1998. 397 p doi:10.2307/2585965

11. FIA Regulations [Internet]. [cited 2018 Jan. 3]. Available from: http://www.fia.com/sport/ regulations/ 
12. Gallian J. NASCAR. Mathematics and Sports; 2010. p. 187-8.

13. Hendrick Motorsports Tops List Of Nascar's Most Valuable Teams [Internet]. [cited 2018

\section{ІНФОРМАЦІЯ ПРО АВТОРІВ}

Білик Олег Любомирович ukrkorfball@gmail.com

Школа вільних та небайдужих,

вул. Клепарівська, 39, м. Львів

Хіменес Христина Робертівна http://orcid.org/0000-0002-8677-6701, khimenes@gmail.com

Львівський державний університет фізичної культури імені Івана Боберського,

вул. Костюшко, 11, м. Львів, 0936718879

\section{INFORMATION ABOUT THE AUTHORS}

Bilyk Oleg ukrkorfball@gmail.com

Physical education teacher, School of the Free and Indifferent,

Kleparivska Street, 39, Lviv, 1, 0976433130

Khimenes Khrystyna http://orcid.org/0000-0002-8677-6701, khimenes@gmail.com

Lviv State University of Physical Culture named after Ivan Boberskyi,

Kostushko Street, 11, Lviv, Ukraine, 79007
14. International Journal of Sport Finance [Internet]. [cited 2018 Jan. 16]. Available from: http:// ijsf.wordpress.com

15. Jones B. (2005). The Guide to 2005 FIA Formula One World Championship: The World's Bestselling Grand Prix Guide. Carlton; 2005.

16. Lucsko D. Real NASCAR: White Lightning, Red Clay, and Big Bill France. Chapel Hill, North Carolina: University of North Carolina Press; 2010. $348 \mathrm{p}$.

17. Menard P. The Great Encyclopedia of Formula 1. 5th edition. Chronosport, Switzerland. 2006. 49 p.

18. Miltner H. Race Travel Guide 2007. Vienna, Austria; 2007. 68 p.

19. Standings NASCAR [Internet]. [cited 2018 Jan. 15]. Available from: http://www.nascar.com/ en_us/sprint-cup-series/standings.html

20. Vamplew W. (1988). Pay Up and Play the Game. Professional Sport in Britain. Cambridge: Cambridge University Press; 1988. 65 p. doi:10.1017/CB09780511560866

Надійшла 27.11.2020 